\title{
TQM KAO MOGUĆNOST UNAPREĐENJA HOTELSKO-TURISTIČKE INDUSTRIJE U BOSNI I HERCEGOVINI
}

\author{
Dalibor Musa $^{8}$
}

UDK / UDC: 005.6:640.4(497.6)

JEL klasifikacija / JEL classification: L83, L15

DOI: https://doi.org/10.22598/pi-be/2020.14.1.91

Prethodno priopćenje / Preliminary communication

Primljeno / Received: 14. svibnja 2019. / May 14, 2019

Prihvaćeno za tisak / Accepted for publishing: 15. svibnja 2020. / May 15, 2020

\section{Sažetak}

Iako Bosna i Hercegovina posjeduje veoma raznolik $i$ u velikoj mjeri očuvan prirodni i kulturni turistički potencijal, njena hotelsko turistička industrija, s obzirom na te mogućnosti, nije ni približno razvijena. Premda ima pozitivne trendove glavnih pokazatelja rasta u zadnjih deset godina, turizam nije u potpunosti iskoristio svoje potencijale. Svjetska turistička organizacija (eng. World Tourism Organization) je Bosnu i Hercegovinu definirala kao jednu od tri turističke destinacije u svijetu s ukupnim potencijalom rasta turističkog tržišta od 10,5\% (za razdoblje do 2020. godine). Također, ova visoka stopa rasta odražava jako nisku baznu vrijednost sektora jer trenutno sektor turizma u Bosni i Hercegovini čini samo 0,2\% ukupnog europskog turizma. Jedan od načina kojima bi se sektor turizma i hotelijerstva, kao njegovog neizostavnog dijela, unaprijedio i krenuo bržim razvojem je uvođenje sustava kvalitete u sve uslužne djelatnosti ovog sektora a s posebnim fokusom na hotelijerstvo. Cilj ovog rada je ukazati na prednosti uvođenja i primjene TQM-a (eng. Total Quality Management) koje osiguravaju dalje razvitak $i$ poboljšavanja kvalitete u turizmu $i$ hotelijerstvu Bosne i Hercegovine. Uvođenjem TQM-a poduzeća podižu kvalitetu svojih proizvoda i usluga čime postaju konkurentniji na tržištu. Ovim standardom poduzeća su „prisiljena" na satno poboljšanje svojih proizvoda i usluga, čime postaju produktivniji $i$ konkurentniji na tržištu.

Ključne riječi: TQM, kvaliteta proizvoda i usluga hotelske industrije, produktivnost, konkurentnost.

\footnotetext{
${ }^{8}$ Dr. sc. Dalibor Musa, izvršni menadžer, VINMAR d.o.o., Široki Brijeg, Bosna i Hercegovina, E-mail: dalibormusa3@gmail.com
} 


\section{UVOD}

Suvremeni uvjeti poslovanja smatraju kvalitetu jednim od jako važnih preduvjeta opstanka i razvoja svakog gospodarskog društva. Stoga ponuđači proizvoda i usluga nastoje svoje poslovne sustave temeljiti na potrebama i zahtjevima svojih kupaca, što je dovelo do razvoja nove filozofije upravljanja i vođenja poslovnih sustava - Upravljanje potpunom kvalitetom (TQM-Total Quality Management). Iako se sustav kvalitete primarno razvio u proizvodnim gospodarskim društvima, vrlo brzo je svoju primjenu našao u uslužnom sektoru, a time i u turizmu i hotelijerstvu.

I sama Svjetska turistička organizacija Ujedinjenih naroda (UNWTO, 2016.c) naglasila je važnost upravljanja kvalitetom kao ključnog faktora za konkurentnost turističkih odredišta i hotela te je to i definirala:

"Pokazatelji i procesi upravljanja kvalitetom ključni su alati za konkurentnost turističkih destinacija ... integrirani pristup upravljanju kvalitetom kao prioritet $\mathrm{u}$ dugoročnom strateškom planiranju destinacijskih organizacija za upravljanje na nacionalnoj i podnacionalnoj razini.“”

„Filozofija potpune kvalitete donijela je posve novi način gledanja na kvalitetu.“(Lazibat, 2009).

Turizam i hotelijerstvo Bosne i Hercegovine, zbog brojnih komparativnih prednosti u odnosu na druge djelatnosti, može biti pouzdana i efikasna tržišna mogućnost za izlazak Bosne i Hercegovine na međunarodno tržište. Međutim, iako posjeduje značajne turističke potencijale, ona se još uvijek nalazi u ranoj fazi razvoja. Jedan od načina kojima bi se sektor turizma i hotelijerstva, kao njegovog neizostavnog dijela unaprijedio i krenuo bržim razvojem, uvođenje je sustava kvalitete u sve uslužne djelatnosti ovog sektora.

Upravljanje kvalitetom $u$ hotelijerstvu je veoma složeno jer ono treba osigurati visoku razinu kvalitete smještaja, ishrane i drugih usluga koje su prateće aktivnosti u hotelijerstvu, a bez kojih gost nema potpunu uslugu. To nije nimalo lagan zadatak za ova gospodarska društva jer ona moraju pronaći načine kako i s kakvom organizacijom će pomiriti svoje potrebe za ostvarivanjem profita uz istodobno zadovoljavanje potreba gostiju, ali i svojih radnika i suradnika/vjerovnika kao i društvene zajednice. Uvođenjem sustava TQM oni će te potrebe zadovoljiti. TQM sustav će osigurati da gospodarsko društvo stvara: osobnu poslovnu kulturu, bolju komunikaciju među zaposlenima, sustav nagrađivanja, rješavanja konfliktnih situacija u samom gospodarskom društvu, način uvođenja promjena kao i pravila o horizontalnom i vertikalnom kretanju po hotelu itd.

\section{DOSADAŠNJA ISTRAŽIVANJA}

TQM, koji je predmet razmatranja ovog rada, kao i sama kvaliteta imaju više definicija: 
- „Način upravljanja poslovnim procesima kako bi se osiguralo zadovoljstvo kupca na svakoj razini (interno i eksterno). To je pristup koji vodi do povećanja konkurentnosti, efikasnosti i fleksibilnosti cijele organizacije“( Oakland, 2003).

- „To je niz aktivnosti koje se provode u cijelom gospodarskom društvu kako bi se ostvarili njegovi ciljevi na efektivan i efikasan način te osigurali proizvodi i usluge one razine kvalitete koja zadovoljava kupca, i to u pravo vrijeme i uz primjerenu cijenu."

- „TQM je kontinuirani proces poboljšanja koji se odnosi na pojedince, grupe ljudi i cijelo gospodarsko društvo."(Kanji, 1996)

Iz navedenih definicija može se zaključiti kako je upravljanje totalnom kvalitetom (TQM) "način poslovanja organizacije koja je usmjerena na zadovoljstvo kupaca primjenjujući kontinuirana poboljšanja.

Gospodarska društva koja posjeduju sustav TQM kontinuirano rade na svom dinamičkom poboljšanju i brzom stvaranju neopipljive imovine koja upravlja industrijskim potrebama.

Jedan broj autora, među njima i Reed i njegovi suradnici još su 1996. godine utvrdili „, kako potpuno upravljanje kvalitetom može generirati konkurentsku prednost gospodarska društva.“

Međutim, neki drugi autori (Prajogo i Sohal, 2006) ističu da ponekad i gospodarska društva koja imaju potpuno upravljanje kvalitetom dožive neuspjeh.

Razlog tome je, zasigurno, što upravljanje kvalitetom traži posvećenost svakog člana gospodarskog društva njegovom provođenju. Potpuno upravljanje kvalitetom je način upravljanja organizacijom usredotočen na kakvoću, utemeljen na sudjelovanju svih članova organizacije te koji zadovoljavanjem korisnika teži za dugoročnim uspjehom i boljitkom za sve članove organizacije (Skoko,2000.).

U svojim početnim fazama nastanka i razvoja, pojam kvalitete se odnosio na proizvode, ali je vremenom prerastao materijalne i uslužne proizvode i proširio se na sve funkcije poslovanja (Stoner et al, 1995) .

Upravljanje kvalitetom je ubrzo postalo veoma značajno i za uspješnost gospodarskih društava u oblasti usluga, a time i u turizmu i hotelijerstvu.

Osnovne karakteristike usluge su:neopipljivost,istodobno odvijanje procesa proizvodnje i procesa potrošnje,specifičan položaj kupca/korisnika,neuskladištivost, nestandardiziranost i neponovljivost „izvedbe“ i kratkotrajnost; odsustvo vlasništva; prolaznost i manja mogućnost standardizacije.

Ove karakteristike se javljaju u različitoj mjeri kod različitih vrsta usluga što znači kako će, ovisno o mjeri u kojoj su one više izražene u pojedinim vrstama usluga,marketing uslužnih organizacija,upravljanje i organizacija ispoljavati veće razlike u odnosu na proizvodne organizacije.

Kod izučavanja kvalitete usluge postoje terminološke neujednačenosti. Kada se govori o kvaliteti usluga pojedini autori upotrebljavaju izraz 'percepcije korisnika o kvaliteti usluge' (engl. customer perceptions of service quality) (npr. Zeithaml et al., 1985.; Sureshchandar, Rajendran i Kamalanabhan, 2001.), dok drugi koriste izraze 
'percipirana kvaliteta usluge' (engl. perceived service quality) (npr. Grönroos, 1984.; Spreng i Mackoy, 1996.) ili skraćeno samo 'percepcije' (engl. perceptions) (npr. Cronin i Taylor, 1994.).

Ako se promatra turizam i hotelijerstvo, kao jedan od sektora usluga, upravljanje kvalitetom u njima, prema Parasurmanu i autorima „mnogobrojna istraživanja su pokazala da korisnici usluga turizma i hotelijerstva ocjenjuju sljedeće karakteristike kvalitete: opipljivost, pouzdanost, sposobnost reagiranja, kompetencije, kurtoaznost, kredibilitet, sigurnost, dostupnost, komunikaciju i razumijevanje“ ( Parasuramann et al, 1985).

„Ove osobine u suštini predstavljaju kriterije koje korisnici usluge koriste pri ocjeni kvalitete usluge.“(Barjaktarović, 2013).

Turizam, kao jedna od najbrže razvijanih grana gospodarstva, nije ostala izvan TQM-a. I vrlo brzo su gospodarska društva, koja su u ovom sektoru primijenila TQM sustav, uvidjela prednosti njegovog uvođenja. Upravljanje kvalitetom u hotelijerstvu je iznimno složeno, jer ono treba osigurati visoku razinu kvalitete smještaja, ishrane i drugih usluga koje su prateće aktivnosti u hotelijerstvu, a bez kojih nema potpune usluge gostu. To nije nimalo lagan zadatak za ova gospodarska društva, budući da moraju pronaći načine kako i s kakvom organizacijom će pomiriti svoje potrebe za ostvarivanjem profita, uz istodobno zadovoljenje potreba gostiju, ali i svojih radnika i partnera/suradnika te društvene zajednice. Stoga je za njih TQM, koji je fokusiran na kvalitetu; koji zahtjeva sudjelovanje svih članova organizacije u ostvarenju ovih ciljeva uz istodobno postizanje zadovoljstva svih članova gospodarskog društva i društva u cjelini, pravi sustav koji će osigurati postizanje njihovih ciljeva i konkurentnosti na tržištu. Osim toga, TQM sustav će osigurati poduzeću stvaranje osobne poslovne kulture, bolje komunikacije među zaposlenima, sustava nagrađivanja, rješavanje konfliktnih situacija u gospodarskom društvu, način uvođenja promjena kao i pravila o horizontalnom i vertikalnom kretanju po organizaciji itd.

U Bosni i Hercegovini, kada je u pitanju turizam i hotelijerstvo, gotovo nitko se nije ozbiljnije nije bavio ovom problematikom. U Federaciji Bosne i Hercegovine donesena su dva zakona s pripadajućim pravilnicima: Zakon o turističkoj djelatnosti (2009) i Zakon o ugostiteljskoj djelatnosti.

Zakonom o turističkoj djelatnosti propisani su minimalno-tehnički uvjeti koje, na primjer, moraju ispunjavati putničke agencije, ali ne i kvaliteta usluga koje se ondje pružaju. Predviđene su novčane kazne za prekršitelje odredbi o ugostiteljskim normativima i kategorizaciji objekata, ali ne i za nekvalitetnu uslugu u tim objektima.

Nažalost ni Zakon o ugostiteljskoj djelatnosti (,Sl.novine FBiH, br.32-09, i Pravilnik o razvrstavanju,minimalnim uvjetima i kategorizaciji objekata iz skupine Hoteli ,Sl.novine FBiH, br.32-10) . Ni ovaj Zakon ne govori o potrebi uvođenju standarda, nego samo određuje minimalne uvjete za obavljanje ove djelatnosti. Minimalni uvjeti i za pravna i fizička lica se odnose na uređenje i opremu ugostiteljskog objekta, usluga , zatim u pogledu projektiranja, građenja, zaštite na radu, protupožarne zaštite, zaštite od buke, zaštite okoliša te odgovarajućih zdravstvenih uvjeta a koji referiraju na zaposleno osoblje. Kada su u pitanju zaposlenici ovaj Zakon definira da oni moraju imati najmanje treći stupanj stručne spreme. 
U Republici Srpskoj je donesen Zakon o turizmu kojim se uređuju oblici njegova planiranja i razvoja, prava i obveze turističkih subjekata, uvjeti za obavljanje turističke djelatnosti, usluge u turizmu, promocija i unapređenje turizma, poticaji $\mathrm{u}$ turizmu, evidencija u turizmu, upravni nadzor i druga pitanja od značaja za razvoj i unapređenje turizma.

U Republici Srpskoj Zakon o ugostiteljstvu uređuje uvjete za obavljanje ugostiteljske djelatnosti, vrste ugostiteljskih objekata, oblike ugostiteljske djelatnosti, kategorizaciju ugostiteljske djelatnosti, prava i obveze ugostitelja, upravni nadzor i ostala pitanja od značaja za oblast ugostiteljstva. kvalitetom.

Ni jedan ni drugi zakon u Republici Srpskoj ne govori o upravljanju

\section{TRENUTAČNO STANJE SUSTAVA KVALITETE U TURIZMU I HOTELIJERSTVU U BOSNI I HERCEGOVINI}

Posljednjih godina, u Bosni i Hercegovini, turizam je postao brzorastući sektor koji sve više postaje važan dio državnog gospodarstva. Prema ostvarenim rezultatima u gotovo svim segmentima, Bosna i Hercegovina se svrstala u red država koje su ostvarile značajan turistički razvoj pa je tako u razdoblju nakon završetka rata (19952000.), broj dolazaka turista, prema podacima objavljenim od strane Agencije za statistiku $\mathrm{BiH}$, rastao u godišnjem prosjeku od $24 \%$. Prema podacima ove Agencije , trend porasta broja turista koji posjećuju Bosnu i Hercegovinu nastavljen je i idućih godina te je prosječan godišnji rast iznosio oko $20 \%$, što je Bosnu i Hercegovinu svrstalo u vrh zemalja koje doživljavaju ekspanziju razvoja turizma.

Agencija za statistiku BiH u biltenu Statistika turizma dala je podatke da su , u periodu siječanj - prosinac 2017., turisti ostvarili 1.307 .319 posjeta, što je više za $13,7 \%$ i 2.677 .125 noćenja, što je više za $12,3 \%$ u odnosu na isti period 2016 . godine. Broj noćenja domaćih turista viši je za 3,8\%, dok je broj noćenja stranih turista viši za $16,2 \%$ u odnosu na isti period 2016. godine. U ukupno ostvarenom broju noćenja učešće domaćih turista je $28,5 \%$ dok je $71,5 \%$ učešće stranih turista. U strukturi noćenja stranih turista najviše noćenja ostvarili su turisti iz Hrvatske $(11,8 \%)$, Srbije $(8,1 \%)$, Turske $(7,3 \%)$, Italije $(5,7 \%)$, Slovenije i UAE s po $(5,3 \%)$ i Poljske $(4,8 \%)$, što je ukupno 48,3\%. Turisti iz ostalih zemalja ostvarili su 51,7\% noćenja. Od ukupnog broja turističkih posjeta prosječno se oko $53 \%$ dolazaka odnosilo na područje Federacije, oko $44 \%$ na područje Republike Srpske, dok se ostatak od 3\% odnosio na područje Brčko Distrikta.

U tablici 1. dat je prikaz broja dolazaka i noćenja domaćih i stranih turista $u$ Bosni i Hercegovini u posljednjih deset godina. 
Tablica 1. Broj dolazaka i noćenja turista u Bosnu i Hercegovinu u razdoblju od 2006. do 2016. godine

\begin{tabular}{|c|c|c|c|c|c|c|}
\hline & \multicolumn{3}{|c|}{ Broj dolazaka } & \multicolumn{3}{c|}{ Broj noćenja } \\
\hline Godina & $\begin{array}{c}\text { Ukupno } \\
\text { dolasci }\end{array}$ & $\begin{array}{c}\text { Strani } \\
\text { turisti }\end{array}$ & $\begin{array}{c}\text { Domaći } \\
\text { turisti }\end{array}$ & $\begin{array}{c}\text { Ukupno } \\
\text { noćenja }\end{array}$ & $\begin{array}{c}\text { Noćenja } \\
\text { stranih } \\
\text { turista }\end{array}$ & $\begin{array}{c}\text { Noćenja } \\
\text { domaćih } \\
\text { turista }\end{array}$ \\
\hline 2006 & 499.244 & 243.480 & 255.764 & 1.177 .452 & 594.380 & 582.082 \\
\hline 2007 & 583.742 & 277.290 & 306.452 & 1.336 .159 & 694.507 & 641.652 \\
\hline 2008 & 610.817 & 289.306 & 321.511 & 1.396 .485 & 718.750 & 677.735 \\
\hline 2009 & 572.634 & 261.692 & 310.642 & 1.268 .173 & 671.128 & 597.045 \\
\hline 2010 & 656.333 & 365.454 & 290.879 & 1.416 .691 & 772.754 & 643.937 \\
\hline 2011 & 686.148 & 391.945 & 294.203 & 1.504 .205 & 836.005 & 668.200 \\
\hline 2012 & 747.827 & 438.585 & 309.242 & 1.645 .521 & 931.081 & 714.440 \\
\hline 2013 & 844.189 & 528.579 & 315.610 & 1.822 .927 & 1.108 .905 & 714.022 \\
\hline 2014 & 846.581 & 536.354 & 310.227 & 1.711 .400 & 1.088 .472 & 623.008 \\
\hline 2015 & 1.029 .000 & 678.271 & 536.354 & 2.143 .118 & 1.425 .761 & 717.357 \\
\hline 2016 & 1.148 .530 & 776.889 & 371.641 & 2.376 .743 & 1.641 .421 & 735.322 \\
\hline
\end{tabular}

Izvori :Agencija za statistiku Bosne i Hercegovine

Uz rast broja turista koji su posjećivali područje Bosne i Hercegovine, rastao je i broj ostvarenih noćenja u svim tipovima smještajnih objekata.

Prema podacima Agencije za statistiku, prosječna dužina boravka gostiju je relativno niska i kreće se oko 2,43 dana, dok se broj ostvarenih noćenja kretao u prosjeku od 2 do 2,1 noćenja. Najveći broj turističkih dolazaka ili noćenja registriran je u planinskom, primorskom, topličkom (banjskom), vjerskom i kulturnom turizmu. Tijekom posljednje dvije godine u smještajnim objektima različitog tipa ostvareno je oko 4,5 milijuna noćenja.

Tablica 2. Pregled noćenja domaćih i stranih turista prema klasifikaciji djelatnosti u 2015. i 2016.godini.

\begin{tabular}{|c|c|c|c|c|}
\hline Smještajni objekti & $\begin{array}{c}\text { Dom. turisti } \\
\text { noćenja } \\
2015 .\end{array}$ & $\begin{array}{c}\text { Dom. turisti } \\
\text { noćenja } \\
2016 .\end{array}$ & $\begin{array}{c}\text { Strani turisti } \\
\text { noćenja 2015. }\end{array}$ & $\begin{array}{c}\text { Strani turisti } \\
\text { noćenja } \\
2016 .\end{array}$ \\
\hline Hotel i sličan smještaj & 656.661 & 663.364 & 1.340 .556 & 1.533 .847 \\
\hline $\begin{array}{c}\text { Odmarališta i slični } \\
\text { objekti za kraći odmor }\end{array}$ & 17.855 & 23.271 & 56.133 & 58.126 \\
\hline $\begin{array}{c}\text { Kampovi i prostori za } \\
\text { kampiranje }\end{array}$ & 1.983 & 2.275 & 13.454 & 19.033 \\
\hline Ostali smještaj & 40.858 & 46.416 & 15.618 & 30.415 \\
\hline Ukupno & 717.357 & 735.322 & 1.425 .761 & 1.641 .421 \\
\hline
\end{tabular}

Izvor: Agencija za statistiku Bosne i Hercegovine 
Kad je riječ o smještajnim objektima iz prikazanih tablica jasno je kako je najveći broj noćenja ostvaren u objektima tipa hotel. Prema podacima Federalnog Zavoda za statistiku i Republičkog zavoda za statistiku Republike Srpske, na području oba entiteta i Brčko Distrikta u 2016.godini radilo je 236 hotela čiji je smještajni kapacitet oko 33 tisuće kreveta. Prosječna iskorištenost kreveta tijekom 2016. godine na području Federacije Bosne i Hercegovine bio je 27,6\%.

Prema podacima Ministarstva okoliša i turizma u Federaciji Bosne i Hercegovine je 101 kategoriziran hotel, a prema podacima Ministarstva trgovine i turizma u Republici Srpskoj takvih je 80 hotela, a u Brčko Distriktu samo jedan. Ovi hoteli su kategorizirani kako slijedi:

Tablica 3. Broj kategoriziranih hotela u Bosni i Hercegovini

\begin{tabular}{|c|c|c|c|c|c|c|c|}
\hline Entitet & $1 *$ & $2 *$ & $3 *$ & $4 *$ & $5 *$ & Baština & Ukupno \\
\hline Federacija BiH & & & & 79 & 8 & 14 & 101 \\
\hline Republika Srpska & 1 & 4 & 49 & 28 & 3 & & 80 \\
\hline Brčko Distrikt & & & & 1 & & & 1 \\
\hline
\end{tabular}

Izvor: Obrada autora

Svi hoteli su kategorizirani prema Pravilnicima koje su usvojile entitetske Vlade. Iz prezentiranih podataka vidljivo je da je mali broj hotela koji imaju 4 ili 5 zvjezdica. Ostali hoteli kategorizirani su u hotele s dvije odnosno tri zvjezdice, koji za izbirljivo turističko tržište nude uslugu skromnije kvalitete, što predstavlja ograničavajućeg čimbenika razvoja hotelske industrije u Bosni i Hercegovini.

Pravilnici oba entiteta i distrikta Brčko propisuju uvjete za kategorizaciju hotela. Ovi uvjeti se odnose samo na uvjete koje hotel mora ispuniti u pogledu infrastrukture, a ne i na kvalitetu koju moraju pružiti gostu. Uvođenje TQM je dobrovoljno i ono se, kao i u drugim zemljama, ne propisuju pravilnicima niti Zakonom o turizmu. Nažalost, ne postoje statistike niti registar o broju hotela koji imaju uveden sustav kvalitete ili neki od standarda. Razlog tome je zasigurno taj što uvođenje sustava kvalitete ili uopće neke standardizacije nije obvezan niti jednim Zakonom donesenim na državnoj ili entitetskoj razini. Uvođenje standarda ili TQM-a ovisi o samom menadžmentu hotela koji ocjenjuju hoće li ih uvesti ili ne.

S porastom broja turista koji posjećuju područje Bosne i Hercegovine sasvim sigurno će doći do daljnjeg razvoja turizma i njegovog segmenta hotelske industrije, koja danas (iznimka su Sarajevo, Banja Luka i Mostar) ima relativno nisku iskorištenost kapaciteta, što se bitno odražava na poslovanje. Pored toga, problemi hotelske industrije u Bosni i Hercegovini, točnije problemi najvećeg broja hotela nižih kategorija su needuciran kadar, nemotivirano osoblje i niska razina kvalitete usluge. Za daljnji razvoj hotelske industrije, kao uvjeta za razvoj turizma uopće, neophodno je uvođenje standarda upravljanja kvalitetom koji će, uz ostalo, poboljšati poslovanje hotela i doprinijeti podizanju razine kvalitete na poželjnu razinu. 


\section{METODOLOGIJA I REZULTATI ISTRAŽIVANJA}

Na svjetskoj ljestvici konkurentnosti turizma za 2016. godinu, koju je objavio Svjetski ekonomski forum, Bosna i Hercegovina je dobila svega 3,12 boda, što ju je stavilo na 113. mjesto od ukupno 136 zemalja svijeta ( World Economic Forume,2016). Svjetski ekonomski forum WEF-a ocjenjuje najmanje 14 parametara vezanih uz turizam, od čega i nastaje indeks konkurentnosti. Bosna i Hercegovina je pozitivno ocijenjena u oblasti kulturno-povijesnog blaga, također prema higijeni, a nažalost najlošija joj je infrastruktura. Smještajni kapaciteti, iako se ulažu veliki pojedinačni napori od strane zainteresiranih ulagača, još uvijek nisu dosegnuli željenu razinu.

Uvođenje standarda kvalitete u hotelijerstvo i turizam Bosne i Hercegovine zasigurno su jedan od preduvjet za njihov opstanak i/ili konkurentnost na turističkom tržištu Bosne i Hercegovine i međunarodnom turističkom tržištu. Razvoj turističkog tržišta kao i globalizacija utjecali su na hotelijerstvo tako da svaki pojedini subjekt (hotel) mora ostvariti svoju konkurentsku prednost, ako želi opstati na tržištu. Hoteli koji imaju TQM ostvaruju efikasnost (visoka kvaliteta uz niske troškove). Također, sustav upravljanja kvalitetom omogućava stalno pronalaženje i zadovoljavanje zahtjeva kupaca gdje znanje opet igra ključnu ulogu.

Stoga je predmet znanstvenog istraživanja ovog rada bio analiza stanja uvođenja standarda kvalitete u hotelijerstvo Bosne i Hercegovine i potrebe uvođenja standarda kvaliteta u hotelijerstvu Bosne i Hercegovine. Ovim radom se želio istražiti značaj uvođenja sustava kvaliteta na razvoj samog turizma, a time i gospodarstva Bosne i Hercegovine. Pri tome je bilo bitno identificirati koji čimbenici u specifičnom društvenom kontekstu omogućavaju i olakšavaju njihovo uvođenje i razvoj, a koji procesi ga ograničavaju i usporavaju, što je i glavni pravac istraživanja u ovog rada .

Anketni upitnik koji se koristio u istraživanju sastojao se iz tri dijela: (1) Prvi dio upitnika sastojao se od pitanja kojima su prikupljeni opći podaci o poduzeću. (2) Drugi dio upitnika uključuje analizu trenutnog položaja poduzeća na tržištu. (3) Treći dio upitnika C predstavlja CETSCALU - ljestvicu s ponuđenim tvrdnjama i stupnjevima slaganja od 1 - uopće se ne slažem do 5 - u potpunosti se slažem, gdje su ispitanici bili dužni odabrati odgovarajući stupanj slaganja sa svakom od navedenih tvrdnji. Anketiranje je vršeno u razdoblju od 30.04.2017. do 31.05.2018. godine.

Uzorak za provedeno istraživanje činila su poduzeća koja su registrirana i posluju na području $\mathrm{BiH}$. U procesu istraživanja sudjelovalo je 150 poduzeće, od kojih je 97,3 \% registrirano kao društvo s ograničenom solidarnom odgovornošću, a 2,7 \% kao dioničko društvo. Uzorak je načinjen metodom slučajnog odabira na osnovi ukupnoj broja registriranih poduzeća. Prema glavnoj djelatnosti poduzeća broj ispitanika ima smještajno-ugostiteljske usluge ( $98,7 \%$ ) dok $1,3 \%$ nudi samo smještajne usluge. Najveći broj anketiranih poduzeća ima 3 zvjezdice $(60,7 \%)$, a zatim slijede poduzeća s 4 zvjezdice $(34,7 \%$ ) s 2 zvjezdice je bilo 3,3 posto a $0,7 \%$ ih ima jednu ili 5 zvjezdica.

$\mathrm{U}$ radu je prezentiran $\mathrm{i}$ analiziran dio istraživanja koje autor rada proveo $\mathrm{u}$ dijelu empirijskog istraživanja za potrebe izrade svoje doktorske disertacije u razdoblju od 30.04.2017. do 31.12.2017. godine. Za realizaciju anketnog upitnika korištena je 
metoda osobnog ispitivanja - direktna metoda. Podaci, koji su bili i prikupljeni anketiranjem, obrađeni su u statističkom programu za obradu podataka SPSS.20. Podaci su obrađeni primjenom: deskriptivne statistike, grafičkih prikaza, hi - kvadra testa, $\mathrm{t}$ testa, Pearsonove korelacije, testa linearnosti. Korišteni su i različiti statistički i matematički postupci. Za pregled uzoraka korištena je deskriptivna analiza u obliku frekvencija i postotaka. Razlike između ispitanika analizirane su primjenom hi-kvadrat testa.

U cilju provjere testiranih uzoraka koji su prikupljeni, analizirane su varijable zadovoljstva pretpostavke "normalnosti", za koje se koristi Shapiro Wilk test, ali samo za uzorke manje od 50 ispitanika. Rezultat W predstavlja empirijsku vrijednost (Paul Newbold et al., 2009), a p - vrijednost, uz odgovarajući Shapiro Wilk test se smatra statistički značajnim ili signifikantnim, ako je niža od 0,05 ..

$\mathrm{Na}$ osnovu urađene analize može se zaključiti da 97,3\% ispitanika ili njih 146 nije uvelo sustav za kontrolu kvalitete, dok je samo 4 ispitanika ili 2,7\% to učinilo. Stoga je u daljnjem dijelu analize ovaj uzorak tretiran kao dva odvojena uzorka, koja su podvrgnuta analizi kao odvojeni podaci.

Analizirajući trenutno poziciju anketiranih poduzeća došlo se do podataka da $56,7 \%$ poduzeća posluje više od 10 godina, od 5-10 godina posluje 33,3\%, manje od pet godina $10 \%$. Također, analiza podataka je pokazala da u ispitanom uzorku ima najviše hotela koji imaju između 11 i 30 zaposlenih, čak 80\%, dok $10 \%$ ispitanih ima između 31 i 50 zaposlenih i $10 \%$ do 10 zaposlenih.

Iako najveći broj anketiranih poduzeća posluje više od 10 godina rezultati istraživanja pokazuju da se financijski rezultat ispitanih hotela kretao između 50 i 100 tisuća KM-u $62,7 \%$ slučajeva. Dalje, $14 \%$ ispitanih je imalo prihode između 10 i 50 tisuća KM, a 14\% ispitanih između 200 i 300 tisuća KM prometa. Najmanje ispitanih ima promet između 100 i 200 tisuća KM (6,7\%) odnosno do 10 tisuća KM $(2,7 \%)$.

U analizi trenutnog položaja poduzeća , 62,7\% ispitanih pozitivno posluje, imaju rast i razvoj u svom poslovanju, dok $34 \%$ ispitanih imaju stagnaciju u poslovanju, a $3,3 \%$ ispitanih se nalaze na početku poslovanja, a kada je u pitanju broj turista koji koristi njihove usluge analiza je pokazala da $46 \%$ ispitanih hotelijera imaju između 2 i 5 tisuća turista godišnje, dok $47,3 \%$ njih imaju više od 5 tisuća turista godišnje. Samo $5,3 \%$ ispitanih je odgovorilo kako godišnje imaju posjet između jedne i dvije tisuće turista, dok $1,3 \%$ ostvaruje posjet do jedne tisuće turista.

U analizi dijela upitnika koji se odnosi na Sustav upravljanja kvalitetom došlo se do poražavajućih podataka da 97,3\% ispitanika ili njih 146 nije uvelo Sustav za kontrolu kvalitete, dok je samo 4 ispitanika ili 2,7\% to učinilo. Zbog ove činjenice u daljoj analizi uzorak koji je korišten u istraživanju se tretirao kao dva odvojena uzorka, koja su bila podvrgnuta analizi kao odvojeni podaci.

Poduzeća koja imaju uveden sustav kvalitete su se jednoglasno izjasnila da im je TQM omogućio: siguran opstanak na tržištu $\mathrm{BiH}$, povećanje konkurentnost na njemu, povećanje prihoda i povećanje broja korisnika usluga. TQM je poboljšao kvalitetu ljudskih resursa u ovim poduzećima. Zahvaljujući ovim rezultatima uvođenja TQM , sve četiri poduzeća su potvrdila da imaju liderski položaj na bosansko-hercegovačkom tržištu. 
Poduzeća koja nemaju uveden TQM sustav su samo djelomično zadovoljna svojim trenutnim položajem na tržištu (prosječna ocjena 3,6) iako je veliki broj njih smatra da imaju rast prihoda (prosječna ocjena 4,18) i rast broj korisnika (prosječna ocjena 4,0). Međutim kada su u pitanju ljudski resursi ova poduzeća uglavnom nisu zadovoljni kvalitetom ljudskih resursa u poduzeću, što pokazuje prosječna ocjena od 2,9726 kao ni kvalitetom menadžera u svom poduzeću.

Analiza podataka je pokazala da hoteli, koji imaju Sustav upravljanja kvalitetom, s prosječnom ocjenom 5, smatraju kako je isti omogućio: opstanak na tržištu, povećanje konkurentskog položaja njihove kompanije na tržištu u Bosni i Hercegovini, lidersku poziciju na BiH tržištu, povećanje prihoda. Kada su u pitanju ispitanici koji nemaju Sustav upravljanja kvalitetom, oni se nisu složili s tvrdnjom: da postoje metode na osnovu kojih oni mjere kvalitetu usluga, da je konkurentnost njihovog biznisa na zadovoljavajućoj razini, da su zadovoljni trenutačnom pozicijom na tržištu, da imaju zadovoljavajući rast prihoda posljednjih godina iako su zadovoljni rastom korisnika $\mathrm{u}$ istom periodu. Nisu zadovoljni ni kvalitetom ljudskih resursa $\mathrm{u}$ poduzeću kao ni menadžera.

Poduzeća koja posjeduju TQM sustav imaju procedure koje reguliraju rad zaposlenika, njihove međusobne odnose i odnose s klijentima što umnogome doprinosi i njihovom zadovoljstvu zbog čega su i oni visokomotivirani za postizanje poslovnog uspjeha u radu što ne rijetko dovodi i do liderske pozicije ovih poduzeća.

Tablica 4. Rezultati ispitivanja

\begin{tabular}{|c|c|c|c|c|}
\hline & \multicolumn{2}{|c|}{$\begin{array}{c}\text { Poduzeća koja imaju } \\
\text { uveden sustav kvalitete }\end{array}$} & \multicolumn{2}{c|}{$\begin{array}{c}\text { Poduzeća koja nemaju } \\
\text { uveden sustav kvalitete }\end{array}$} \\
\hline & $\begin{array}{c}\text { Prosječna } \\
\text { ocjena }\end{array}$ & $\begin{array}{c}\text { Std } \\
\text { devijacija }\end{array}$ & $\begin{array}{c}\text { Prosječna } \\
\text { ocjena }\end{array}$ & $\begin{array}{c}\text { Std } \\
\text { devijacija }\end{array}$ \\
\hline $\begin{array}{c}\text { Povećanje konkurentnost } \\
\text { na tržištu BiH }\end{array}$ & 5 & 0 & 3,6 & 0,90221 \\
\hline $\begin{array}{c}\text { Liderski položaj na tržištu } \\
\text { BiH }\end{array}$ & 5 & 0 & 3,6 & 0,79202 \\
\hline Povećanje prihoda & 5 & 0 & 4,1849 & 0,62149 \\
\hline $\begin{array}{c}\text { Povećanja broja korisnika } \\
\text { usluga/proizvoda }\end{array}$ & 5 & 0 & 4,08 & 0,60466 \\
\hline $\begin{array}{c}\text { Poboljšalo kvalitetu } \\
\text { ljudskih resursa u poduzeću }\end{array}$ & 5 & 0 & 2,972 & 0,76907 \\
\hline $\begin{array}{c}\text { Dovelo do zapošljavanje } \\
\text { obrazovanijih menadžera }\end{array}$ & 5 & 0 & 2,788 & 0,772 \\
\hline
\end{tabular}

Izvor: Obrada autora u statističkom paketu SPSS 20.

Istraživanjem se željelo ustanoviti $\mathrm{i}$ da li postoji adekvatna pravna infrastruktura upravljanja kvalitetom koja olakšava uvođenje Sustava upravljanja kvalitetom. Analiza podataka je pokazala da se svi ispitanici, koji posjeduju Sustav upravljanja kvalitetom, slažu s tvrdnjom kako pravna infrastruktura upravljanja 
kvalitetom osigurava djelotvornost ovog sustava i da je glavni uvjet za stjecanje povjerenja i lojalnosti klijenata u sektoru hotelijerstva i turizma. Mišljenja su da neusklađenost zakonske regulative s EU stavlja njihovo poduzeće u inferioran položaj. Ispitanici koji ne posjeduju Sustav upravljanja kvalitetom uglavnom se ne slažu s tvrdnjom kako je pravna infrastruktura upravljanja kvalitetom prisutna u njihovoj kompaniji, ali se slažu s tvrdnjom da je pravna infrastruktura Sustava upravljanja kvalitetom bitna za stjecanje povjerenja i lojalnosti klijenata u sektoru hotelijerstva i turizma. Također smatraju kako postoji problem s neusklađenosti zakonske regulative s EU i čime se i njihovo poduzeće stavlja u inferioran položaj.

\section{ZAKLJUČAK}

Bosna i Hercegovina posljednjih deset godina ima pozitivne trendove glavnih pokazatelja rasta u sektoru turizma, ali to nije ni blizu mogućnostima koje Bosne i Hercegovina realno ima. Jedan od načina kojima bi se sektor turizma i hotelijerstva, kao njegovog neizostavnog dijela unaprijedio i krenuo bržim razvojem, uvođenje je sustava kvalitete u sve uslužne djelatnosti ovog sektora s posebnim fokusom na hotelijerstvo.

Prednosti uvođenja TQM-a u uslužni sektor, turizam i hotelsku industriju su velike, kako gospodarski tako i društveno. Uvođenje sustava kvalitete u hotelijerstvu Bosne i Hercegovine predstavlja nužnost uključivanja u svjetske poslovne trendove i svjetska turistička tržišta. Uvođenje standarda kvalitete u hotelijerstvo i turizam Bosne i Hercegovine preduvjet su za njihov opstanak i/ili konkurentnost na turističkom tržištu Bosne i Hercegovine i međunarodnom turističkom tržištu. Ovo su potvrdili svi ispitanici, koji posjeduju Sustav upravljanja kvalitetom. Oni smatraju kako je njegovo uvođenje apsolutno povećalo konkurentni položaj njihove kompanije na tržištu u Bosni i Hercegovini. Ispitanici koji nemaju Sustav za upravljanje kvalitetom samo se donekle slažu s tvrdnjom da je konkurentnost njihovog biznisa na zadovoljavajućoj razini. S obzirom na to da je mali broj hotela, koji imaju uveden Sustav upravljanja kvalitetom, ne iznenađuju podaci da $34 \%$ anketiranih sudionika smatraju kako imaju stagnaciju u poslovanju i da gotovo $80 \%$ ispitanika imaju prihod između 10.000 i $100.000 \mathrm{KM}$, čime se također potvrđuje kako Sustav upravljanja kvalitetom predstavlja preduvjet za opstanak na bosanskohercegovačkom tržištu.

Analiza podataka je pokazala da hoteli Bosne i Hercegovine koji imaju certificirani sustav kvalitete imaju liderski položaj na tržištu Bosne i Hercegovine. Ispitanici koji nemaju Sustav za upravljanje kvalitetom odgovorili su kako su donekle zadovoljni trenutačnom pozicijom na tržištu. Postojeća zakonska regulativa Bosne i Hercegovine nije usklađena s regulativom Europske unije, što gospodarska društva u djelatnosti turizma i hotelijerstva stavlja u inferioran položaj. Analiza podataka je pokazala kako ne postoji značajna statistička razlika između ispitanika koji posjeduju Sustav za upravljanje kvalitetom i onih koji ga ne posjeduju, po pitanju neusklađenosti zakonske regulative $\mathrm{BiH}$ s EU regulativom te kako time njihova poduzeća stavljaju u inferioran položaj. 
U Bosni i Hercegovini ne postoji Zakon o turizmu. Entiteti i Brčko distrikt imaju nadležnost u sektoru turizma, a također, zakonska regulativa u ovoj oblasti je riješena entitetskim zakonima kao i zakonima Brčko distrikta. Entiteti i Brčko distrikt imaju Pravilnike o kategorizaciji i klasifikaciji ugostiteljskih objekata koji su također neusklađeni. Ovi zakoni i pravilnici nisu u skladu s EU direktivama i standardima. Premda postoji radna skupina za turizam, koja djeluje u okviru Ministarstva vanjske trgovine i ekonomskih odnosa Bosne i Hercegovine, značajnijih pomaka nije bilo. Pri empirijskom istraživanju „veliko iznenađenje“ je bio mali broj hotela koji su uveli Sustav upravljanja kvalitetom. I u izravnom razgovoru s menadžerima hotela većina je mišljenja kako je, na ovom stupnju razvoja turizma u Bosni i Hercegovini, kategorizacija njihov glavni „dokaz“ kvalitete. Nažalost, ni postojeći Zakon o ugostiteljskoj djelatnosti, kao ni pravilnici ne spominju pojam upravljanja kvalitetom. Bosna i Hercegovina, za razliku od turističkih razvijenih zemlja, posebno ne potiče uvođenje Sustava upravljanja kvalitetom. Ni sami hoteli, koji imaju Sustav upravljanja kvalitetom, tu svoju vrijednost ne ističu na vlastitim web stranicama niti u promotivnim materijalima. Istraživanje je pokazalo kako poduzeća, koja imaju spomenuti sustav, imaju veću disciplinu u poslovanju, što uvelike olakšava procese u hotelu i način poslovanja, zadovoljstvo radnika i bolje poslovanje. Tako oni čine zadovoljnim i svoje goste, koji se nerijetko ponovno vraćaju ili preporučuju drugim gostima, čime se zasigurno povećava i sama konkurentnost ovih hotela. Premda je kategorizacija hotela jako važno jamstvo standarda usluge koju gost kupuje, potrebno je naglasiti da se kategorizacija, ipak, odnosi na ispunjavanje uvjeta tehničko-smještajnog uređenja uz pružanje određenih usluga. Ali, ona ne jamči kvalitetu pruženih usluga koje su često neopipljive. Kategorizacija ne jamči kvalitetu usluge, koja u velikoj mjeri ovisi o odnosu uspostavljenom između zaposlenog osoblja u hotelskom poduzeću i gostiju. Taj odnos najviše ovisi o individualnim karakteristikama zaposlenika koji izravno pružaju uslugu. Ovaj segment poslovanja nosi mnogo rizika, jer kvaliteta odnosa i kontakta zaposlenika i gostiju, koji su neposredni, mogu dovesti do pojave određene pogreške, koja se može negativno odraziti na razinu kvalitete pružene usluge, odnosno razinu zadovoljstva gosta pruženom uslugom. Zbog toga je jako važno uspostaviti sustav kvalitete u hotelijerstvu, koji se odnosi na eliminiranje mogućnosti ponavljanja grešaka, prvenstveno u komunikaciji, kao ključa uspjeha dobrog odnosa zaposlenika i gostiju.

Premda zakon ne nameće uvođenje Sustava upravljanja kvalitetom bilo bi dobro, u idućem razdoblju, u Bosni i Hercegovini raditi na promociji uvođenja sustava kvalitete u hotelijerstvu, jer će to dovesti do povećanja njegove konkurentnosti na turističkom tržištu, a također i do povećanja zadovoljstva gostiju, što će se odraziti i na povećanje prihoda u turizmu i dovesti do pozitivnog utjecaja i na državno gospodarstvo. Iznimno bi važno bilo i usvajanje Zakona o turizmu, koji bi omogućio daljnji razvitak turizma. Osim zakona, koji ne bi nametao uvođenja sustava kvalitete, bilo bi dobro da na razini Bosne i Hercegovine, slično kao i u drugim zemljama, Vlada snažnije podrži turistički sektor tako što će stvoriti alat koji bi trebao pomoći pri upravljanju kvalitetom, istodobno ga prilagodivši svim specifičnostima turističkog sektora. Kada je u pitanju pravna regulativa koja se odnosi na turizam i hotelijerstvo, značajno bi bilo donijeti direktive i preporuke koje bi regulirale odnose turista i isporučitelja usluga u 
sektoru turizma, sigurnost turista i druge elemente, po uzoru na direktive i preporuke zastupljene u zemljama Europske unije. Neophodno je donijeti i pravni i regulatorni okvir na razini države Bosne i Hercegovine koji bi regulirao održivi razvoj i upravljanje turizmom; osigurao zaštitu i očuvanje prirodnih i kulturno- povijesnih vrijednosti; definirao odgovornosti svih sudionika uključenih u turizam i hotelijerstvo; osigurao prava turista odnosno pravnu zaštitu; olakšao uključivanja privatnog sektora i lokalnih zajednica u aktivnosti razvoja turizma. Također, posebno bi važno bilo regulirati način vođenja statistike u turizmu i hotelijerstvu, budući da se sada svi statistički podaci, koji se nalaze u Zavodu za statistiku, moraju uzimati s rezervom, jer način njihova prikupljanja nije podržan propisima koji bi osiguravali točnost podataka.

\section{LITERATURA}

1. Agencija za statistiku BiH (2017), Statistika turizma u periodu siječanj - prosinac 2017., Sarajevo

2. Barjaktarović. D. (2013), Uparvljanje kvalitetom u hotelijerstvu, Beograd, Univerzitet Singidunum

3. Cronin Jr J.J., Taylor SA. (1994) Measuring service quality: A reexamination and extension, Journal of Marketing

4. Gronroos, C. (1984), Strategic Management and Marketing in the Service Sector, , London, Chartwell-Bratt

5. Kanji, G.K., Asher,M. (1996), 100 Methods for Total Quality Management, London, Sage Publications,

6. Lazibat, T. (2009), Upravljanje kvalitetom, Zagreb, Znanstvena knjiga

7. Newbold, P., Carlson, W., and Betty Thorne (2009), Statistika za poslovanje $i$ ekonomiju, Zagreb, MATE

8. Oakland, J.S. (2003), Total Quality Management - text with cases, ,Oxford, Third edition, Elsevier Butteworth Heinemann

9. Parasuraman, A., Zeithaml, V.A. and Berry, L.L. (1985). SERVQUAL: A Multiple-Item Scale for Measuring Consumer Perceptions of Service Quality. Journal of Retailing..

10. Prajogo, D.I., Sohal, A.S.(2006) The relationship between organizational strategy, total quality management (TQM), and organization performance-the mediating role of $T Q M$, European Journanl of operational Research, Vol 168 , No1,

11. Pravilnik o razvrstavanju, minimalnim uvjetima $i$ kategorizaciji objekata iz skupine Hoteli, Sl.novine FBiH, br.32-10

12. Reed, R., Lemark, D.J., Montgomery, J.C. (1996) Beyond process: TQM content and firm performance, Academy of Management Review, Vol.21, No1

13. Skoko H (2000), Upravljanje kvalitetom,., Zagreb, Sinergija d.o.o

14. Spreng, R. A., Mackoy, R. D. (1996). An empirical examination of a model of perceived service quality and satisfaction. Journal of Retailing,.

15. Stoner, J A. F. and others(1995), Management, Prentice Hall, Inc.

16. Sureshchandar G.S., Rajendran C., Kamalanabhan T.J., (2001)Customer perceptions of service quality: A critique, Journal Total Quality Managment, Vol.12 
17. UNWTO.(2016). UNWTO tourism highlights. Madrid, United Nations World Tourism Organization

18. World Economic Forume (2016)., Travel and tourism competitiveness report 2016. Geneva,by the World Economic Forume

19. Zeithaml, V.; Berry, L. (1985), Conceptual Model of Service Quality and its Implications for Future Research, Journal of Marketing, Vo-46, No-4, New York

20. Zakon o turističkoj djelatnosti Bosne i Hercegovine ,Službene novine Federacije BiH“, broj 32/09,

21. Zakon o turizmu Republike Srpske ,Službeni glasnik Republike Srpske, broj: 55/03; $63 / 07 ; 101$

22. Zakon o ugostiteljskoj djelatnosti - Sl.novine br.32-09. 


\title{
TQM AS A DRIVER OF HOTEL AND TOURISM INDUSTRY IMPROVEMENT IN BOSNIA AND HERZEGOVINA
}

\author{
Dalibor Musa
}

\begin{abstract}
Summary
Although Bosnia and Herzegovina possesses a very diverse and largely preserved natural and cultural tourism potential, its hotel industry, given these possibilities, is not nearly developed. It is necessary to take up a new, modern and very ambitious attitude towards this area, as tourism can contribute considerably to the development of the economy of Bosnia and Herzegovina. Although it has positive trends of major growth indicators over the last ten years, tourism has not fully exploited its potential. The World Tourism Organization defined Bosnia and Herzegovina as one of the three tourist destinations in the world with a total tourism market growth potential of $10.5 \%$ (for the period up to 2020). Also, this high rate of growth reflects the very low base value of the sector, as currently the tourism sector in Bosnia and Herzegovina accounts for only $0.2 \%$ of total European tourism. One of the ways in which the tourism and hotel sector, as its indispensable part, will improve and move faster, introduces the quality system into all service activities of this sector and with a special focus on hotel industry. The aim of this paper is to point out that the introduction and application of TQM (Total Quality Management) can lead to further development and improvement of quality in tourism and hotels in Bosnia and Herzegovina. Companies which introduce $T Q M$ raise the quality of their products and services thus becoming more competitive on the market. With this standard, enterprise is "forced" to hourly improvement of their products and services, thus becoming more competitive on the market.
\end{abstract}

Key words: TQM, product quality and hotel industry service, productivity, competitiveness. 